\title{
Charismatic Reformer, Mystic or Father? The Reception of Symeon the New Theologian by Pentecostal/Charismatic Theologians
}

\author{
Maxym Lysack
}

Faculty of Theology, Saint Paul University, Ottawa, ON K1S 1C4, Canada; mlysack@ustpaul.ca

\begin{abstract}
The last three decades have seen a renewed interest on the part of Evangelical scholars in patristic studies. Recently, theologians of the Pentecostal/Charismatic tradition have started to examine the works of Saint Symeon the New Theologian. The latter's emphasis on personal experience of the Holy Spirit and Christification provides a fertile ground for encounter between Orthodox and Pentecostal/Charismatic scholars. Recent Pentecostal/Charismatic scholarship on Symeon is reviewed in the light of contemporary Orthodox scholarship. Four key moments in Symeon's teaching on asceticism are presented in response to two Pentecostal/Charismatic theologians.
\end{abstract}

Keywords: Symeon the New Theologian; Orthodox spirituality; Pentecostal/Charismatic spirituality; mysticism; asceticism; apatheia

Citation: Lysack, Maxym. 2021. Charismatic Reformer, Mystic or Father? The Reception of Symeon the New Theologian by Pentecostal/ Charismatic Theologians. Religions 12: 389. https://doi.org/10.3390/ rel12060389

Academic Editors: Bradley Nassif and Tim Grass

Received: 30 April 2021

Accepted: 26 May 2021

Published: 27 May 2021

Publisher's Note: MDPI stays neutral with regard to jurisdictional claims in published maps and institutional affiliations.

Copyright: (C) 2021 by the author. Licensee MDPI, Basel, Switzerland. This article is an open access article distributed under the terms and conditions of the Creative Commons Attribution (CC BY) license (https:// creativecommons.org/licenses/by/ $4.0 /)$.

\section{Introduction}

Evangelical Christians have been interested in the history of the Early Church since the time of the formation of Evangelical churches themselves. It was only a question of time before Evangelical scholars would discover one of the logical ancillary areas associated with Early Christianity: patristic studies. While much of the attention of Evangelical scholars has been directed towards the Apostolic Fathers, Saint Augustine and the Fourth-Century Fathers, a recent interest in Saint Symeon the New Theologian (ca. 949-1022) can now be detected among Pentecostal/Charismatic theologians. This is a welcome development that should be acknowledged warmly by Orthodox theologians. In this article, I would like to recognize some of the work on Symeon by Pentecostal/Charismatic theologians and share some insights from modern Orthodox scholarship that might prove helpful to them in their ongoing reception of him. I would also like to point out some potential pitfalls.

My intention is not to analyze recent Orthodox scholarship in detail; instead, I propose to highlight important moments in that scholarship that give us keys to understanding Symeon. When placing the latter insights beside those of contemporary Pentecostal/Charismatic scholars, we notice right away the possibilities for further conversation. The conversation from the Pentecostal/Charismatic side has already begun. Now I believe it is time for Orthodox theologians to respond to Pentecostal/Charismatic theologians. As a modest beginning, I suggest four areas in Saint Symeon's teaching on asceticism for further consideration. The idea is to respond to Pentecostal/Charismatic theologians from within the work of Saint Symeon himself and engage in the conversation by explicating some of the salient points from the New Theologian's teaching on asceticism.

\section{The Life and Witness of Saint Symeon}

Saint Symeon the New Theologian was an Orthodox monk who lived in the tenth and eleventh centuries. He is called "Theologian" by the Church because of the profound knowledge and experience of God that can be observed in his life and writings. He is known as the "New Theologian" because he follows in the great tradition of Saint John the Apostle and Saint Gregory Nazianzen, who are also called "Theologians" by the Church. 
While it is possible, and even likely, that the appelation New Theologian was attributed derisively to Saint Symeon by his opponents, the Orthodox Church rejoices in the title, knowing that the Church affirmed unreservedly both the holiness of the Saint and the orthodoxy of his teaching.

\section{Historical Context}

Several aspects of the society in which Saint Symeon was born and raised are important for understanding the development of his vocation and his emergence as one of the major monastic figures of his time. Symeon was born in an empire that had reached the peak of its political, economic, and cultural development. It was a Christianized empire in which both the emperor and the patriarch played very important parts. The relationship between the Church and the state and, more specifically, between the patriarch and the emperor is commonly described by the term symphonia. While this term is suggestive of a peaceful coexistence between Church and state, we must not ignore the fact that the two often held each other in check. Falling into disfavour with the patriarch, for example, might not be absolutely fatal if one had powerful friends at the imperial court. Such was in fact the case with Symeon, who was rescued by supporters who had great influence with the emperor during times when he faced the opposition of the patriarchal office (Golitzin 1997, p. 37).

The Byzantine empire of the time of Saint Symeon was, as we have noted, enjoying economic prosperity and some successes in its diplomatic policies, which were reflected in some brilliant advances in mission work and some victories on the battlefield. Symeon spent his youth and virtually his entire adult life in the capital of this empire, Constantinople. Even the time spent in exile by Symeon was lived just across the Bosphorus from the capital city. What is striking in him is the contrasting approaches he took to Constantinople and all that it symbolized: he both profoundly rejected and intentionally embraced the city. On one hand, Symeon passionately rejected a career of service to the state. Symeon's parents had sent him to Constantinople as a young boy with precisely such a career in mind. Symeon's entrance into the monastic life signals both his escape from the future his family had planned for him and a repudiation of what he no doubt saw as the more distasteful aspects of political life. On the other hand, Symeon is what Metropolitan Kallistos terms "an urban hesychast" (Ware 1986, p. 238). His was not the eremetical life of the desert or the idiorrhythmic life of the skete. There was nothing quiet or pastoral about the situation of Symeon's monastery; it was in the heart of the capital city of the empire. In this sense, Symeon projects the image of a cosmopolitan monk who is conversant with all of the issues of his day and acquainted with the most powerful figures in both the Church and the state. I do not in any sense believe that Symeon's theological positions were determined by his historical and geographical situation. It is easy to see, however, how his cosmopolitan character meshed very well with his theological conviction that a personal experience of the presence of the Holy Spirit and the practice of contemplative prayer were normative for the laity as well as the monks.

Father George Maloney, commenting on the monasticism of Symeon's day, refers to it as being in a state of decay:

Eastern Christianity at this period of Byzantine political power had settled down into a "smug symphony" with the State. Byzantine monasticism had become ossified by institutionalizing its liturgical and contemplative forms of prayer. The Typicon regulating how many prayers and bows were to be performed by the monks had replaced the Holy Spirit. There was need, not for another St. Theodore the Studite to legislate for monasticism, but for a new Pentecost. The Byzantine Church was crying for a charismatic leader to bring Christians back to the living God of Abraham, Isaac and Jacob. (Maloney 1975, p. 10)

No doubt Father Maloney is overstating his case somewhat. He also seems to forget that Saint Theodore the Studite brought true renewal to the monasticism of his time. More importantly, however, Father Maloney has introduced into the study of the life and work of Saint Symeon a specific historical narrative that poses certain risks. Ought we to see the 
Studite tradition as ossified and Symeon as a charismatic reformer? Is Symeon rebelling against the Studite monasticism of his time? Is Symeon the representative of an older tradition that has been forgotten in 10th- and 11th-century Constantinople? It would be appealing to think so. Symeon's character certainly seems to reflect the personality of a charismatic reformer. Exciting as such a hypothesis would be, it is certainly not supported by current scholarship (McGuckin 1996).

Archbishop Alexander Golitzin presents us with a more sober assessment of Saint Symeon's historical context than does Father Maloney. Golitzin speaks of a golden age of the Christian empire that included a kind of golden age for monasticism (Golitzin 1997, p. 17). It is precisely because of this golden age that many of Symeon's contemporaries did not understand the prophetic nature of his ministry.

For the purposes of St. Symeon's life, it is sufficient here to underline the notes of triumphalism and conservatism which dominated the symphony of Church and state in the Byzantium of his day. His own melody would therefore strike many of his contemporaries as discordant, impossibly jarring, and perhaps heretical. He was faced with constant opposition. Others, however, would recognize in his song the strains of a tune that was older than Constantine's alliance of Church and state, one indeed coeval with the Christian gospel (ibid., pp. 17-18).

\section{Different Interpretations in Secondary Literature}

In virtually all of the contemporary scholarship on Saint Symeon, we find an attempt to discover the main influences on his thought. Many scholars emphasize the connection in terms of theological content and vision between Saint Symeon and Saint Makarios (Krivocheine 1986, p. 31; Ware 1986, p. 238). Both placed a great emphasis on the need for a personal experience of the action of the Holy Spirit. We also know from Symeon's Life by his disciple Nicetas Stethatos (ca. 1005-1090) that Symeon's elder, Saint Symeon the Pious, gave him Saint Mark the Ascetic to study in his younger years (Stethatos 2013, chp. 4, para. 2). At a later point in his life, Saint Symeon was studying the writings of Saint John Klimakos, and it seems that Saint Symeon took much from them in certain areas (ibid., chp. 6, para. 2). Some scholars refer to the marriage of cenobitic monasticism in the tradition of Saint Theodore the Studite and eremetical monasticism in the Sinaite tradition, a marriage that characterizes Saint Symeon's writings (Sylvia Mary 1976, p. 99; Ware 1986, p. 238). Since it is hard to determine all of the major patristic influences on Saint Symeon, it seems safer to follow the intuition expressed by Golitzin, who says quite simply that Saint Symeon is the inheritor of all the best in the Orthodox tradition and follows in the mainstream of the development of patristic theology exemplified by the dogmatic pronouncements of the Ecumenical Councils (Golitzin 1997, p. 11).

Modern scholarship also provides us with a variety of opinions regarding the theological orientation of Saint Symeon's work. Some, including Metropolitan Kallistos and Sister Sylvia Mary, find in Saint Symeon a profound Christological orientation (Ware 1986, p. 240; Sylvia Mary 1976, p. 98). Father Alexis Torrance not only ascribes a Christological character to Symeon's writings, but interprets them in an explicitly Chalcedonian/NeoChalcedonian framework (Torrance 2020, pp. 134-38). Vladimir Lossky, on the other hand, states that Saint Symeon's major contribution to Orthodox theology is more in the area of his Pneumatology (Lossky 1973, p. 117). Father Louis Bouyer perceives St. Symeon's writings to have both a strong Christological and Pneumatological character (Bouyer 1968, p. 568).

Orthodox scholarship on Symeon in the West began to develop more substantially after the works of Saint Symeon were published in a critical edition in Sources Chrétiennes. Archbishop Basil Krivocheine served as one of the editors of the Sources Chrétiennes volumes and was well placed to write a monograph on Saint Symeon that quickly became a classic in recent scholarship (Krivocheine 1986). The Archbishop, however, was unable to cover all of the aspects of Symeon's work in one volume. A second work on Symeon, designed explicitly as a sequel to Krivocheine's, emerged more than two decades later 
(Alfeyev 2000). The former work positioned Symeon as a theologian, a mystic, and a Father. The latter placed Symeon even more firmly within the context of the patristic tradition. Subsequent Orthodox scholarship took exception to the notion that Symeon was either a radical reformer of monasticism or an inheritor of an identified spiritual tradition and approached Symeon as an eleventh-century Orthodox monk on his own terms and in his historical context (McGuckin 1996). In a book that appeared very recently in English, Orthodox theologian and priest Nikolaos Loudovikos sounds a note of caution regarding Symeon, warning against reading him as a mystic in the Origenistic-Augustinian tradition (Loudovikos 2019, p. 99). Loudovikos sees Symeon as a Father and considers him, together with Saints Maximos the Confessor and Gregory Palamas, as one of the three most significant architects of Orthodox Christian theology (ibid., pp. 264-65). His identifying Symeon as a Father is, of course, nothing new: Krivocheine and Alfeyev do the same. What is significant in Loudovikos's work, however, is the legacy he assigns to each of the three Fathers: Maximos, Symeon and Palamas (ibid., pp. 257-58).

In recent years, Saint Symeon has begun to attract the attention of Evangelical scholars, in particular those of the Pentecostal/Charismatic tradition. It is easy to understand why theologians of the Pentecostal/Charismatic tradition are attracted to Symeon the New Theologian. Symeon speaks about the need to experience the Holy Spirit consciously. He chastises those who teach that a Christian may have the Holy Spirit without having any awareness of it. He uses the expression "baptism in the Holy Spirit" and describes the latter as an experience that each Christian must choose and that is clearly one that occurs subsequent to the sacrament of Baptism. It would be easy to read the baptism in the Holy Spirit as a second experience of the grace of God and draw parallels with Wesleyan and Pentecostal/Charismatic teaching. Pentecostal/Charismatic theologians and writers have already noticed the potential parallels. In a book review in The Pneuma Review, Dony K. Donev writes concerning the three volumes published by St. Vladimir's Seminary Press St. Symeon the New Theologian on the Mystical Life: The Ethical Discourses:

The trilogy presents the New Theologian as new in name, but old in religion and original in the personal experience of God. This fact proves that through the ages, there have always been people searching for God with an open heart and experiencing His presence in a Pentecostal manner. It further defines the Pentecostal experience of the Spirit as the true restoration of the Early Church praxis. And finally, it proves that Land's thesis that Pentecostalism is more Orthodox than Catholic and more Eastern than Western. (Donev 2006)

Orthodox scholars may find the last statement particularly endearing. Pentecostal/ Charismatic scholars are finding something immensely attractive in Saint Symeon and are making him a kind of link figure between the posited charismatic experience of the early Church and the Pentecostal/Charismatic movement of today. Donev refers to Stephen Jack Land, who wrote a recognized history of Pentecostal spirituality. Land, of course, is interested in locating important precursors of Pentecostal spirituality and finds them in the person of Symeon the New Theologian, as well as in Gregory of Nyssa and Macarius the Egyptian. He posits that Pentecostalism is more Eastern than Western in its spirituality and, very significantly, adopts theosis as a fundamental tenet of Pentecostal spirituality (Land 2010, p. 30). That Symeon is a theologian of the Holy Spirit par excellence is undeniable. That he insists on a personal appropriation of the work of the Holy Spirit is again more than evident in his writings. Is Symeon experiencing God's presence in a Pentecostal manner? Here I think we need to be cautious and give the question more consideration. Donev notes the importance of the sacraments in Symeon's writings but does not remark on the emphasis that the latter places on the Eucharist. For Symeon, the Eucharist is irreplaceable. In addition, Symeon emphasizes the role of asceticism in the Christian life. Donev does not mention asceticism at all, but I should point out that he is only writing a book review, not an analytic essay. In short, the ascetic and eucharistic context for Symeon's writings provides a specific framework for his experiences, and because of this framework, it would be difficult to make the claim that Symeon is having what modern-day Pente- 
costals and Charismatic Christians would term a Pentecostal experience, or the baptism in the Holy Spirit, as they normally interpret it. I will return to the importance of asceticism and the Eucharist in Symeon's writings later. Clearly, however, there is an opening for dialogue between Orthodox and Pentecostal/Charismatic Christians on this particular issue, and given the openness of the latter to the discovery of a significant Pneumatology in the Christian East, it is an opportunity that should not be missed.

In another article published in The Pneuma Review, republished from the Quodlibet Journal, author Gene Mills makes the connection between the two baptisms in the Pentecostal tradition and the two in the work of Saint Symeon (Mills 2019, p. 1). In the case of the latter, Mills identifies the baptisms as the sacramental Baptism (combined with Chrismation in the Eastern Christian tradition), administered by Symeon's time in infancy, and the baptism of tears, a spiritual baptism of purification that is received later, and only with the express desire of the recipient (ibid., pp. 1-3). Mills does not state explicitly what the two baptisms are in the Pentecostal tradition, but we are left to infer that they must be Baptism in water after conversion and the baptism in the Holy Spirit at a later juncture. Mills posits that the teaching on two baptisms is a hallmark of Pentecostalism and finds what he considers a parallel tradition in the theological work of the New Theologian (ibid., p. 4). It is an intriguing point of departure, especially given that the Pentecostal tradition is not normally considered sacramental. If we set the question of the first, or sacramental, Baptism aside for the moment, we are left with the opinion of the author that the baptism of the Holy Spirit in the Pentecostal/Charismatic experience and the baptism of tears (also called baptism of the Holy Spirit-Symeon uses both expressions) in the writings of the New Theologian are analogous. Mills' assertion is very close to the hypothesis advanced by Donev that the Pentecostal experience runs through the entire history of the Church.

Mills takes seriously Symeon's conviction that Baptism performed in infancy is efficacious. He also places Symeon's teaching on the two baptisms into a larger narrative on deification (ibid., p. 1). What is curious, however, is the author's contention that Symeon's position on the sacrament of Baptism celebrated in infancy accurately reflects the teaching of the Orthodox Church but that the Saint's position on the baptism of tears represents a fundamental departure from it (ibid., p. 3). In a footnote, he concedes that the teaching on the baptism of tears can be found in patristic spiritual literature and identifies the standard antecedents in the tradition (ibid., p. 5, n. 14). I would suggest that this is an overstatement on the part of the author. Symeon's teaching on the baptism of tears is part of the overarching theme of repentance in his writings. Father John McGuckin argues convincingly that repentance is indeed the key for understanding Symeon's theological work (McGuckin 2020). Symeon distinguishes himself in the tradition by expressing his position with great conviction and by insisting that the baptism in the Holy Spirit is a sine qua non for all Christians, but if we understand the baptism as purification, we do not find an innovation here. Mills understands the importance of repentance in Symeon's writings and links it with penthos (Mills 2019, p. 3), but he does not seem to position Symeon firmly in the existing tradition on the point of the baptism of tears.

Finally, Mills criticizes Symeon for locating his understanding of holiness within asceticism:

Symeon was inescapably bound to his context, and as such, he found holiness only in the extreme asceticism of the monastic life. This is neither practical, nor desirable, for most Christians today. Yet can this also be one of the loudest clarion calls Symeon has for us? Could it be that we have complicated our lives to the point that we have made any concept of theosis an impossibility without such a radical change in lifestyle? (ibid., p. 4)

I can understand that Mills finds asceticism as it is described in patristic texts alien to his own tradition. Later in this article, I will attempt to describe the dynamics of asceticism in Symeon's writings. I believe that Mills and other theologians of the Pentecostal/Charismatic tradition can find much of benefit in Symeon's teachings on this topic and even some things that might be familiar. What will become apparent, however, is that 
Symeon does not locate asceticism in monastic practice exclusively. As for Symeon being bound to his context, I can hardly see this aspect of his thinking as problematic. Indeed, what historical figure is not connected to a historical context? Good scholarship on Symeon will take precisely this context into account in order to get a proper understanding of him.

Recently, a monograph on Saint Symeon the New Theologian written by a theologian from the Charismatic tradition appeared in print and significantly advanced Pentecostal/Charismatic scholarship on Symeon. The book The Immediacy of God in Symeon the New Theologian demonstrates a sympathetic approach to the New Theologian. The study on Symeon, a revision of the author's Master's thesis (McInnes 2017, p. ix), is well documented and offers some good insights into Symeon's work. To an even greater extent, however, the book will serve as a scholarly introduction to Symeon for Evangelicals, particularly those of the Pentecostal/Charismatic persuasion. The author, Jim McInnes, is well acquainted with Orthodox scholarship on Symeon and has obviously made a serious and laudable effort to gain a fundamental grasp of Orthodox theology. McInnes summarizes Symeon's teaching in this way:

The baptism of repentance with tears brought cleansing to the soul enabling it to see God. Deification by means of the Spirit through the Eucharist is essentially the same process, which is why Symeon stressed the importance of tears and conscious awareness of Christ while participating in communion. It is all of a piece. Both sacraments-Baptism and Eucharist-demand the same true knowledge, experience and contemplation that were earlier equated with participation in God. (ibid., p. 154)

McInnes grounds Symeon's teaching very appropriately, in my view, in the sacraments of Baptism and the Eucharist. The Christian life begins with Baptism and finds its perfection in the Eucharist. Repentance and purification enable deification to take place. Symeon states that every Christian must be aware of the process to be a true participant in it. This simple but accurate summary of Symeon's teaching provides the correct framework for interpreting everything else. If the author had simply followed through on this summary by using it as a hermeneutic for interpreting the "mystical" passages in Symeon, his book would have been even stronger, in my view. The problem begins when Symeon is interpreted as a mystic first and then his teaching is analyzed later, often in a way to support the initial assumption. McInnes, however, is entirely aware of the problem, and observes that the most recent scholarship on Symeon addresses the earlier imbalance of seeing Symeon as a mystic to the exclusion of everything else (ibid., p. 11). Here is where Orthodox scholarship can help. It is developing in the same direction, addressing Symeon as a Father of the Church first and foremost, or as a spiritually gifted eleventh-century monk who assumed charismatic authority from his spiritual father. Both approaches have their strengths and bring something important to contemporary scholarship, although I feel that the former better places Symeon in the context of the tradition as a theologian.

McInnes's thesis, of course, is that Symeon's teaching is characterized by an emphasis on the immediacy of God, hence the title of the book. The expression "immediacy of God," however, seems to be used synonymously with mysticism, so we are back into the pursuit of Symeon as a mystic in one way or another. As McInnes himself states:

A study of the immediacy of God is, after all, a study of mysticism, not monasticism, or asceticism, or history, or theology, as important as these lenses are for making sense of our tenth-century Byzantine monk. (ibid., p. 172)

The author's approach certainly does not invalidate his research but, in my opinion, it places certain restrictions on how far he can go with certain good intuitions that he has. For example, the author well understands Symeon's great emphasis on the importance of the Eucharist. He devotes a section to it and makes the connection with the Incarnation in Symeon's theological work (ibid., pp. 148-55). Nevertheless, he does not make the Eucharist the perfecting event that it is in Symeon's writings, the event that conditions all his mystical teaching. Not surprisingly, he therefore evaluates visions, voices, and 
ecstatic encounters as phenomena (ibid., p. 173). He quite understandably explores vision, conscious awareness, mystical experience of light, and receptivity to mystical grace as moments of mystical experience (ibid., pp. 172-98). We can hardly fault the author for doing so: his is the standard approach to mysticism that we can see in many academic studies among theologians and students of spirituality. ${ }^{1}$ The study of mysticism thus becomes a precise science, and with the scientific analysis of it, academics can undertake to construct its history and explain its standard characteristics. While there is some truth in this approach, it may not actually tell us fully who Symeon is. Instead, it may obscure important elements of his teaching and remove him from his place in the tradition.

One of the most challenging and even perilous moments to interpret in Symeon's writings are his visions. While McInnes describes the two visions of Christ that we find clearly presented in Symeon's work, one before and the other after the Saint entered the monastic life (ibid., pp. 35-42), he notes that a distinction needs to be made between ecstatic states and regular, continuing visionary revelation (ibid., 192). The author poses the question of whether Symeon had a visible radiance and comes to the conclusion that he did not (ibid., p. 189). Perhaps an important question is: Visible to whom? Apart from this particular question, an answer needs to be given regarding the meaning of vision. Father John McGuckin explores this question in great detail in the article that McInnes indicates he was unable to obtain (ibid., p. 11, n. 29). In this article, McGuckin, an Orthodox theologian, applies insights of historical criticism to Symeon's vision texts (McGuckin 1997). McGuckin opines that many theologians have applied a Transfigurationist hermeneutic to the visions in order to connect them with the teaching of classical hesychasm, a teaching that would only emerge fully in the fourteenth century (ibid., pp. 94-97). He opposes this approach and finds instead that the visions are a way to message repentance (ibid., pp. 102-7). One may dispute the utility of historical criticism as a method in this instance, and one may also agree or disagree with McGuckin's contention that the visions message repentance, but what is most important in the article, in my opinion, is McGuckin's insistence on moving the discussion of the visions outside of the presumed context of mystical experiences in the usual sense imputed to them by many scholars.

McInnes cites Lossky on numerous occasions and observes that Lossky understands vision as referring to an existential communion (McInnes 2017, p. 180). Here is an important key provided by Lossky: the visions need to be understood as part of the Christian life and not simply as isolated ecstatic experiences. Perhaps we might reposition the visions in this new context supplied by Lossky and draw the conclusion that the visions are an expression of the union of the created with the uncreated, a union or communion that might properly be termed Christification.

McInnes observes that asceticism in Symeon's thought leads to dispassion and purification to illumination (ibid., pp. 105-6). Here is where we can incorporate the insights of Father Nikolaos Loudovikos, who indicates that mysticism and spirituality are potentially dangerous categories for theology. Specifically, he identifies a stream of mysticism originating in the Christian tradition with Origen and continuing through Augustine to Nietzsche. He eschews the illumination of the Augustinian school and warns of an ontology of power implicit in much of western mysticism (ibid., pp. 28-62). ${ }^{2}$ Furthermore, he contends that hesychasm is also being misread through this same Augustinian lens (ibid., pp. 3-4). Loudovikos identifies the Augustinian understanding of illumination as a prominent feature of this pernicious mysticism. In his most recent publication in English, Loudovikos dedicates a substantial chapter to Saint Symeon. Here is what he has to say about the vision of God in Symeon:

In the most profound Christocentric thought of Saint Symeon, the Eucharistic indwelling of the incarnate Word as Light is knowledge, as a conjunction of love and vision, repentance and illumination. In this sense, the vision of God means the manifestation of Christ as the supreme, self-emptying encounter between persons and not any Neo-Platonic enlightenment and mystic subjectivism. (ibid., p. 112) 
I hasten to point out that I do not believe that McInnes understands the vision of God in Symeon as Neoplatonic illumination. My intention, rather, is to indicate the risk involved in treating the visions as an aspect of mystical experience. In addition, we can see from Loudovikos what a central role the Eucharist plays in Symeon's thought, and I would suggest that the Eucharist, not mysticism, is the key for understanding Symeon.

As I indicated earlier, I would like to return to the question of asceticism in Symeon's thought. I believe that there are two important moments in his thought that could prove beneficial to Mills in his exploration of Symeon's corpus of writings and two that might prove helpful to McInnes. For Mills, the two moments that I believe would serve to make his study more complete are the positive character of asceticism in Symeon's work and the baptism of the Holy Spirit as a purgative experience. For McInnes, the two moments are the importance of the body and alleged lapses into Neoplatonic thinking in Symeon, as well as the acquisition of virtues and apatheia as a dynamic process.

\section{The Positive Character of Asceticism}

In his Seventh Ethical Discourse, Saint Symeon tackles the question of the character of asceticism using a verse from the Gospel of Luke as a point of departure. Symeon's position is simple: asceticism must be more than cutting off the passions. The verse he uses is Luke 11:23, "He who is not with me is against me, and he who does not gather with me scatters" (Symeon the New Theologian 1996, Seventh Ethical Discourse, p. 84). "Gathering" in this case means acquiring virtues, and Symeon insists that the one who is not actively acquiring is in fact moving backwards in the spiritual life (ibid.). The stress here is on a positive activity that passes beyond the avoidance of sin. In the spiritual life, the removal of sinful thoughts and actions must be linked with the emergence of virtue. This is a feature of Symeon's thought that McInnes highlights in his book (McInnes 2017, p. 107). Mills, on the other hand, does not seem to engage with this positive aspect of Symeon's asceticism.

In the same discourse, Symeon also deals with the question of the purpose of asceticism. He is emphatic in stating that ascetic acts are not a service to God (Symeon the New Theologian 1996, Seventh Ethical Discourse, p. 86). We practise asceticism out of concern for ourselves and for our own salvation (ibid.). It is likely that Saint Symeon was aware of the destructive impact that a wrong view of asceticism could have on the life of his own monastery and that he spoke out of concern for the health of his own monastic community. He wanted to make very sure that asceticism did not surreptitiously become the goal of the Christian life. If God were to be served by asceticism, the latter would become the objective rather than a means of the spiritual life. Here Evangelicals can rest assured that asceticism is not a "work" apart from or in place of the grace of God. Instead, asceticism represents the practice of spiritual disciplines that serve to make us more open to the grace of God. God gives His grace freely, but our openness to that grace is often limited or compromised due to our own woundedness or inattentiveness. Ascetic disciplines help us increase our availability to God and assist us in apprehending the grace that He grants us. I suspect that Mills could find something familiar and useful in Symeon's teaching for his own tradition. Not everything from the monastic tradition is "extreme" or disconnected from the current context for Christians.

\section{The Baptism of the Holy Spirit Is Purgative}

Saint Symeon discusses the way in which the Holy Spirit manifests Himself in the life of a Christian. In the first place, the entrance of the Holy Spirit into the life of a believer is contingent upon the will and desire of the Christian (p. 98). Clearly, one of the objectives of asceticism is to provide this desire for and openness to the Holy Spirit. Next, Symeon says, the fire of the Holy Spirit is ignited, and the Christian is completely engulfed in it. This, he says, is not without "unbearable pain" (p. 99). The pain is the result of all of the sins and their effects being burned out of the person of the Christian. This is what we might call the "purgatory" of Saint Symeon's spiritual theology: it is part of the ascetic life in this world. Beyond the purgative stage, we discover the experience of great light and joy (ibid.). 
Through this immersion in the Holy Spirit, the Christian gains a much deeper awareness of $\sin$ (ibid.). The basic principle that Symeon is establishing here is that the ability to see one's sins is preceded by purification from sin. This might strike many as peculiar, but the point of this teaching is that we must receive a certain degree of healing before we become properly conscious of our own illness. The human being without the Holy Spirit is so desperately ill that he or she cannot even clearly reflect on his or her own condition. A little progress in the spiritual life finally allows the person to see his or her own state for what it is. Evangelicals of the Wesleyan tradition will find something familiar here, as will those of the Pentecostal/Charismatic tradition. Wesley was known to have read spiritual masters of the Christian East and to have found much of value in them. It would be oversimplifying to state that Saint Symeon, Wesley, and contemporary Pentecostals/Charismatics are saying the same thing, but there are some points of intersection. The baptism in the Holy Spirit in Symeon's theological thought is purgative but results in deeper joy and peace. There may be parallels between the New Theologian's baptism in the Holy Spirit and John Wesley's second work of grace, and they are worth exploring, but they are not directly germane to our discussion of asceticism here. It seems clear, however, that we cannot associate the baptism in the Holy Spirit in Saint Symeon with the baptism of the Holy Spirit with glossolalia as evidence in the Pentecostal/Charismatic tradition. Mills seems well aware of that and proposes that speaking in tongues not be the only sign of the presence of the Spirit. He sees the baptism of tears as being another legitimate indication of the advent of the Spirit (Mills 2019, p. 5, n. 23).

\section{The Importance of the Body in Asceticism and the Alleged Lapses into Neoplatonism}

McInnes states that "Symeon sometimes treats the body as a material prison from which the immaterial soul only finds a kind of Platonic salvation through departure" (McInnes 2017, p. 136). He continues: "Consider, for example, his comment that believers are currently deprived of union with God 'because they are held by the body, and sheltered, and covered, alas, like prisoners under guard ... for they cannot strip off the shackles of the body.' Here McInnes is citing a phrase from Symeon's Hymn 27, but he has stopped the citation too early. Here is the rest of the sentence: "Even if they are set free of the passions and every attraction, but having been set free of many passions, they are held by one" (Symeon the New Theologian 2010, Hymn 27, lines 106-107). Here is the critical point: even one passion can render the body a prison of sorts. Symeon continues:

For one who has been bound in many fetters does not hope to find release from the many, but one who has been able to cut through most of the fetters, but remains held by one, is more distressed than the others, and is eager, and always seeks release from it, in order to appear free, to walk rejoicing, so to go in haste towards their desire, on this account one seeks deliverance from this fetter. Accordingly, let us all seek Him who alone is able to free us from the fetters! (ibid., lines 108-117)

Do the fetters represent the body? Clearly not! They represent the passions. Symeon is saying that the awareness of imprisonment by the passions becomes more acute in those who are freed from them almost entirely. They long to put off their last fetter in order to be fully free. It is not the release from the body that they are seeking; it is the release from the oppressive passions that render life in the body a prison. ${ }^{3}$

When Saint Symeon speaks of the soul's being set afire with the Holy Spirit, he is careful to add that the body may also participate in the same experience and reality:

After these things have been utterly destroyed and the essence alone of the soul remains, quite without passion, then the divine and immaterial fire unites itself essentially to the soul, too, and the latter is immediately kindled and becomes transparent, and shares in it like the clay pot does in the visible fire. So, too, with the body. It, too, becomes fire through participation in the divine and ineffable light. (Symeon the New Theologian 1996, Seventh Ethical Discourse, p. 99). 
Here Symeon gives us an unmistakable indication of the high regard he has for the body in his theological anthropology. He stands apart from that stream of spirituality that is highly influenced by Neoplatonism. For Symeon, the body is neither a prison nor an encumbrance, but an essential part of the human person that participates equally with the soul in the full experience of the divine presence. The reader must keep in mind this tenet of Symeon's theological anthropology in order to properly understand other references in his writings that appear more ambiguous. An example of this apparent ambiguity follows:

We sleep on the ground, and many of us bind our bodies with iron chains. Why? In order, of course, to break this lusty body and weigh it down and not allow it ... to drag itself and the intellect which rides it ... into the abyss of damnation and everlasting fire. (ibid., p. 89)

The above passage could be disturbing if one had no means to interpret it. The reference to "weighing the body down" might appear to offer more than a hint of Neoplatonism. Additionally, Symeon does not speak disapprovingly of monks binding their bodies with iron chains. Nevertheless, he is very clear in stating the purpose of these disciplines: it is to prevent the flesh from taking control of the entire human person. Most importantly, it is the lusty body that must be broken, not the body cured from the passions. Monks historically have been given to rather extreme forms of asceticism from time to time, although the expressions of ascetic discipline in Symeon's monastery and time would doubtless have been more moderate than certain practices that can be observed in early monasticism. When passages referring to such ascetic practices are seen through the lens of Symeon's theological anthropology, however, they take on a new and different meaning. The genius of Symeon's anthropology is that it allows monasticism to retain the full rigour of its ascetic tradition within the context of a Christian view of the human body. Here we find a way for Christians from the Pentecostal/Charismatic tradition to put otherwise difficult passages from ascetic literature into a proper theological context.

\section{Acquisition of Virtues and Apatheia as a Dynamic Process}

McInnes states that asceticism in Symeon leads to dispassion (apatheia) (McInnes 2017, p. 106). He also observes that passions must be rehabilitated in order for virtues to be acquired (ibid., p. 107). There is, however, a dynamic acquisition of the virtues in Symeon's work that leads upwards to the acquisition of apatheia. Even apatheia, however, should not be understood as a static state. Critically, the ascetic ascent ends with a personal encounter with Christ. It is communion with Christ that gives the fullest meaning to asceticism.

In the Eleventh Ethical Discourse, Saint Symeon writes: "God has arranged for everything to be in order and by degrees. Indeed, just as islands in the deeps of the sea, so should you picture with your mind the virtues to be in the midst of this life" (Symeon the New Theologian 1996, Eleventh Ethical Discourse, p. 132). Symeon argues that there is a certain progression or growth in the virtues and that each degree opens up the next level. He does state, however, that a certain precondition is required before the journey through the virtues can even be started. This precondition is the giving of our life. Symeon states that the virtues must be purchased with our blood (ibid., p. 131). A refusal to die means that no progress in the virtues is made: "Truly, unless one is slaughtered like a sheep for any single virtue and pours out his own blood for it, he will never possess it. God has so ordered it that we receive eternal life by means of our voluntary death" (ibid.).

Saint Symeon understands humility to be the gateway to all the other virtues (ibid.). Without it, none of the other virtues can be attained. After humility, Symeon lists mourning, then meekness, then hunger and thirst for righteousness, then mercy and compassion, then purity, and finally, the vision of God (p. 132). Symeon, it seems, took the Beatitudes as his inspiration for the degrees of virtue. He makes a very important addition to this schema: the condescension of Christ. Symeon writes: "If we ascend just a little at the beginning of the ascetic journey, Christ condescends to meet us" (pp. 133-34). Here the Saint is stressing that the final end of asceticism is an encounter with Christ. The idea of progression from 
virtue to virtue is a completely biblical one that finds its model in the Second Epistle of Saint Peter (2 Peter 1: 3-9).

\section{Degrees of Apatheia}

Progression along the pathway of the virtues leads to higher and higher degrees of apatheia or dispassion. Saint Symeon even suggests that there are different degrees here (Symeon the New Theologian 1996, Fourth Ethical Discourse, p. 15). He speaks of the apatheia required to forgive completely those who have wounded us and "to embrace them dispassionately as true friends without the least trace of dislike making its nest in the soul" (ibid.). An even higher level of dispassion is displayed by the person who maintains this level of spiritual composure in the midst of temptation when he or she is being insulted and hurt by other people. Symeon pushes the point further, however, in suggesting that there is a yet higher level of apatheia:

I am also of the opinion that there is a stage yet incomparably higher than the last: to have arrived at complete forgetfulness of whatever it is one may have suffered and never to recall it, whether those who have done the injury are present or not, and, in addition, to behave toward these people, whether in conversation or at table, as toward friends, without having any second thoughts. These are the works of men who walk in the light. (pp. 15-16)

What is striking about the highest degree of dispassion described by Symeon is that it is clearly beyond the normal capability of even the least self-centred person. This type of apatheia is not a learned skill and cannot be achieved through the simple imitation of Christ's behaviour as described in the Gospels. Apatheia is not merely the highest possible level of consciousness that can be achieved by an ascetic; it is nothing less than the fullness of Christ's life made real in a human person.

\section{Asceticism as a Means, Not an End}

Saint Symeon understands asceticism to be an indispensable part of the life of a Christian. At the same time, he is equally aware that it is a means, or better yet, a path to the true objective of the Christian life, which is both the immersion in the Holy Spirit and a direct encounter with Christ. Symeon's writings are equally Pneumatocentric and Christocentric. A high degree of apatheia characterizes the advanced stages of the ascetic life. Apatheia on its own, however, is not properly speaking the objective of asceticism; rather, it is a way for us to describe the existential state of a person who has reached full communion with Christ, or theosis. Symeon describes this in another way by using the expression "wholly with God" (p. 32). While theosis is a term that would not be embraced by all Evangelical theologians, "wholly with God" is a state that all Evangelicals could accept wholeheartedly.

In the Fourth Ethical Discourse, Saint Symeon insists that the profound transparency to Christ that typifies the highest level of apatheia is possible in this life. He is able to make this claim because he experienced it in his own life (p. 41). It is his own experience, which is either articulated explicitly in his work or is implicit in many of his teachings, that makes what he has to say about the ascetic life so credible and so attractive. Symeon becomes the guide who can initiate the Christian into the spiritual life, the theologian who can give the spiritual life its deepest meaning, and the master who can lead his disciple to the spiritual heights.

\section{Conclusions}

The purpose of this article was threefold: (1) to note key moments in contemporary Orthodox scholarship on Symeon; (2) to recognize contemporary Pentecostal/Charismatic scholarship in the light of the latter; and (3) to begin a conversation based on four salient points in the New Theologian's teaching on asceticism. Contemporary Orthodox scholarship on Saint Symeon the New Theologian is resistant to the idea of approaching Symeon as a charismatic reformer, cautious and occasionally openly opposed to viewing him as 
a mystic, and much inclined, of course, to receive him as a Father. The latter point is a rather important one for Orthodox theologians. Pentecostal/Charismatic scholarship finds Symeon extremely attractive, ponders the possibility of seeking spiritual and theological roots in the Christian East, and is much less resistant to viewing Symeon as a mystic. For reasons that are understandable, Pentecostal/Charismatic theologians may not feel the need to pose the question about the reception of Saint Symeon as a Father. This kind of comparison is useful in theology because it allows us immediately to see divergences and convergences. In this article, I have endeavoured to observe these moments without making any attempt to create them. Pentecostal/Charismatic theologians and Orthodox theologians come from different theological traditions, so divergences are entirely natural. At the same time, I have tried to highlight some convergences that might come as a surprise to Orthodox theologians: the deep interest of Pentecostal/Charismatic theologians in Orthodox Pneumatology, their proposal to relocate themselves "Eastward" with regard to the patristic teaching on theosis, and the beginning of an effort to appreciate the importance of the sacraments and the ascetic life. I must admit to not having been aware of these moments until I read the work of the Pentecostal/Charismatic theologians featured in this article. I think that most Orthodox theologians would have predicted an interest on the part of Pentecostal/Charismatic theologians only in Symeon's teaching on the baptism of the Holy Spirit. We see, however, that the situation is quite different.

In my view, the logical place for a conversation to start is with the New Theologian's teaching on the ascetic life. In his discussions on asceticism, Symeon broadly combines theological anthropology, Christology, and eschatology, providing an excellent synthesis of his teaching. He links asceticism to theosis, and having discovered Land's assertion that Pentecostal spirituality is partially aligned with Orthodox theology on this point (Land 2010), I became convinced of the wisdom of using the Saint's teaching on asceticism as a basis for initiating a conversation. For these reasons, I responded to Mills by suggesting two moments and to McInnes with two moments. Each of the moments was chosen in response to the individual author's work. For Mills, Symeon's stress on the positive aspect of asceticism allows the author to see Christian asceticism as something current and relevant, a necessary part of discipleship that stretches beyond the confines of eleventhcentury monasticism. Confronting the baptism of the Holy Spirit as a purgative experience would allow the theologian and author to pursue further study of this "second" baptism within the resources of his own tradition while maintaining an awareness of some of the potential divergences between the Orthodox and Pentecostal/Charismatic traditions on this point. When I came to McInnes, I understood the substantial commitment that he had made to researching Symeon's works on the academic level. I suggest two moments that would allow for greater theological definition. The first one, that Saint Symeon is firmly committed to a Christian understanding of the body despite language that sometimes suggests an intrusion of Neoplatonism, may sound like an overly arcane point, unworthy of further consideration. I was inspired, however, by Father Alexis Torrance's approach to Symeon as a Chalcedonian and Neo-Chalcedonian thinker (Torrance 2020). If Torrance is right, Symeon could not embrace Neoplatonic thought to any significant degree. McInnes has done his research on this point and is fully aware of how different scholars align themselves. As for the dynamic nature of the acquisition of virtues and apatheia in Saint Symeon, it is a beautiful moment in Symeon's thought, one that links the acquisition of apatheia to Christification. This moment in Symeon's teaching provides a fine complement to McInnes's work and an important reminder of the New Theologian's enduring commitment to the possibility, and indeed necessity, of attaining theosis in this life, a hallmark of his teaching.

The reception of Symeon by Pentecostal/Charismatic theologians is only beginning. It will no doubt provide a fertile ground for exchange. We can only look forward to the work that will be done in the future.

Funding: This research received no external funding.

Conflicts of Interest: The author declares no conflict of interest. 


\section{Notes}

1 Some classic studies of Christian mysticism include Evelyn Underhill's Mysticism: A Study in the Nature and Development of Spiritual Consciousness (Underhill 1911), Dom Cuthbert Butler's Western Mysticism: The Teaching of Augustine, Gregory and Bernard on Contemplation and the Contemplative Life (Butler 1922), and Bernard McGinn's monumental series The Presence of God: A History of Western Christian Mysticism (McGinn 1991). While few would question the possibility of studying mysticism and especially of writing its history, Orthodox theologians see all theology as spiritual and sense a danger in allowing spirituality to become a phenomenon of its own, detached from the classic Christian teaching about the Incarnation, Crucifixion, and Resurrection of Christ. See Loudovikos's comment "Christ did away with 'spirituality' through the Incarnation, putting in its place God as Man" (Loudovikos 2019 , p. 4). Alexander Schmemann, a noted Orthodox liturgical theologian of the previous generation, expressed similar reservations in his book on Baptism and Chrismation (Schmemann 1974, pp. 72-74). He connects the spiritual life with Baptism, Chrismation, and the Eucharist. Giorgios Mantzarides states that "Spirituality is an abstract concept which has no place in the tradition of the Orthodox Church" (Mantzarides 1994, p. 8). Not all Orthodox scholars, however, subscribe to the aforementioned position; some use the terms 'spirituality' and 'mysticism' within an established framework. See, for example, Nicholas Arseniev's work on mysticism in the Eastern Church, a work that ends with a chapter on ecclesial mysticism based on the Eucharist (Arseniev 1979, pp. 120-47). Lossky also uses the terms 'mysticism' and 'spirituality' without difficulty, although he is careful to link the latter with the dogmatic tradition of the Church (Lossky 1976, pp. 9-11).

2 Loudovikos indicates that the intellect is the highest aspect of the soul in Augustinian thought. The will, however, makes the intellect ecstatic, allowing the latter to project itself toward the divine light or, as Loudovikos observes, to assert itself over what is not considered truly spiritual by Augustine, including the body. Loudovikos notes that it is here, among other places, that Augustinian thought betrays its Neoplatonic origins. The soul is seen to be superior to the body and as possessing a spark of the divine. The movement of the intellect made ecstatic by the will is not, in Loudovikos's opinion, a movement towards incorporation into Christ, God made Man, but rather an aggressive movement that demonstrates the ontology of power. Loudovikos considers that the ontology of power lies behind much of what is usually considered mysticism and spirituality and that it reaches its apogee in Nietzsche's nihilism. Perhaps some will not accept the assertion that Nietzsche's Übermensch derives spiritually from Augustine and that Nietzsche is an inheritor of what Loudovikos terms Augustinian spiritualism; however, the critique of Augustine's theological anthropology and the associated implications for the spiritual life need to be given serious consideration. Loudovikos is likely not the first contemporary Orthodox theologian to critique Augustine and to make the connection to Nietzsche's philosophy of the will. It seems that Metropolitan John Zizioulas developed this idea earlier (Zizioulas 2006, pp. 46-47). While Loudovikos follows in part the contours of Zizioulas's argument, his critique expands beyond the question of consciousness and the will treated by Zizioulas and embraces virtually all aspects of theological anthropology.

3 Passions are God-given natural energies that have been corrupted by sin. They need to be cured and rehabilitated through life in Christ. While the body can be afflicted by passions, it is inherently good. We must be careful to distinguish between the disease and the afflicted organism. Discussion of the passions and their treatment or rehabilitation has a long history in the patristic and early Christian tradition reaching back to Origen and Evagrios, continuing through Saint Maximos the Confessor and Saint John of the Ladder, and reaching a moment of refined articulation in the great Hesychast Fathers Saint Gregory of Sinai, Saint Gregory Palamas, and their successors. For a magisterial work on passions and their treatment, published in three volumes in English, see Dr. Jean-Claude Larchet's Therapy of Spiritual Illnesses: An Introduction to the Ascetic Tradition of the Orthodox Church (Larchet 2012).

\section{References}

Alfeyev, Hilarion. 2000. St. Symeon the New Theologian and the Orthodox Tradition. Oxford: Oxford University Press.

Arseniev, Nicholas. 1979. Mysticism and the Eastern Church. Translated by Arthur Chambers. Crestwood: St. Vladimir's Seminary Press.

Bouyer, Louis. 1968. Byzantine Spirituality. In A History of Christian Spirituality II: The Spirituality of the Middle Ages. Edited by Dom Jean Leclercq, Dom François Vandenbroucke and Louis Bouyer. New York: The Seabury Press, pp. 547-90.

Butler, Dom Cuthbert. 1922. Western Mysticism: The Teaching of Augustine, Gregory and Bernard on Contemplation and the Contemplative Life. London: Constable and Company.

Donev, Dony K. 2006. St. Symeon the New Theologian, On the Mystical Life: The Ethical Discourses. The Pneuma Review. Fall. Available online: http: / pneumareview.com/st-symeon-the-new-theologian-on-the-mystical-life-the-ethical-discourses (accessed on 2 March 2021).

Golitzin, Alexander. 1997. St. Symeon the New Theologian, On the Mystical Life: The Ethical Discourses, Vol. 3: Life, Times and Theology. Crestwood: St. Vladimir's Seminary Press. 
Krivocheine, Basil. 1986. In the Light of Christ. Translated by Anthony P. Gythiel. Crestwood: St. Vladimir's Seminary Press.

Land, Stephen Jack. 2010. Pentecostal Spirituality: A Passion for the Kingdom. Cleveland: CPT Press.

Larchet, Jean Claude. 2012. Therapy of Spiritual Illnesses: An Introduction to the Ascetic Tradition of the Orthodox Church. Translated by Fr. Kilian Sprecher. Montreal: Alexander Press.

Lossky, Vladimir. 1976. The Mystical Theology of the Eastern Church. Translated by a Small Group of Members of the Fellowship of St. Alban and St. Sergius. Crestwood: St. Vladimir's Seminary Press.

Lossky, Vladimir. 1973. The Vision of God. Translated by Asheleigh Moorhouse. Leighton Buzzard and Bedfordshire: The Faith Press.

Loudovikos, Nikolaos. 2019. Analogical Identities: The Creation of the Christian Self. Turnhout: Brepols Publishers.

Maloney, George A. 1975. The Mystic of Fire and Light. Denville: Dimension Books.

Mantzarides, Giorgios. 1994. Orthodox Spiritual Life. Translated by Keith Schram. Brookline: Holy Cross Orthodox Press.

McGinn, Bernard. 1991. The Foundations of Mysticism:Origins to Fifth Century, Volume 1 of The Presence of God: A History of Western Christian Mysticism. New York: The Crossroad Publishing Company.

McGuckin, John Anthony. 1997. The luminous vision in eleventh-century Byzantium: Interpreting the biblical and theological paradigms of St Symeon the New Theologian. In Work and worship at the Theotokos Evergetis 1050-1200. Edited by Margaret Mullet and Anthony Kirby. Belfast: Belfast Byzantine Enterprises, The Queen's University of Belfast, pp. 90-123.

McGuckin, John Anthony. 2020. Repentance as Divine Communion in St. Symeon the New Theologian's Hymns of Divine Love. International Journal of Orthodox Theology 11: 1. Available online: https://www.orthodox-theology.com/media/PDF/1.2020 /JohnAnthonyMcGuckin.pdf (accessed on 12 April 2021).

McGuckin, John A. 1996. Symeon the New Theologian (d. 1022) and Byzantine monasticism. In Mount Athos and Byzantine Monasticism. Edited by Anthony Bryer and Mary Cunningham. Aldershot: Ashgate Publishing Ltd.

McInnes, Jim. 2017. The Immediacy of God in Symeon the New Theologian. Auckland: Sunesis Press.

Mills, Gene. 2019. The Baptism of Tears: The Two Baptisms of St. Symeon the New Theologian. The Pneuma Review. Spring. Available online: http:/ / pneumareview.com/the-baptism-of-tears-the-two-baptisms-of-st-symeon-the-new-theologian (accessed on 2 March 2021).

Schmemann, Alexander. 1974. Of Water and the Spirit: A Liturgical Study of Baptism. Crestwood: St. Vladimir's Seminary Press, pp. $72-74$.

Stethatos, Niketas. 2013. The Life of Saint Symeon the New Theologian. Dumbarton Oaks Medieval Library 20. Translated by Richard P. H. Greenfield. Cambridge: Harvard University Press.

Sylvia Mary, Sister. 1976. Symeon the New Theologian and the Way of Tears. In One Yet Two: Monastic Tradition East and West. Edited by M. Basil Pennington. Kalamazoo: Cistercian Publications, pp. 95-119.

Symeon the New Theologian. 2010. Divine Eros: Hymns of Saint Symeon the New Theologian. Translated by Daniel K. Griggs. Crestwood: St. Vladimir's Seminary Press.

Symeon the New Theologian. 1996. St. Symeon the New Theologian, On the Mystical Life: The Ethical Discourses, Vol. 2: On Virtue and Christian Life. Translated by Alexander Golitzin. Crestwood: St. Vladimir's Seminary Press.

Torrance, Alexis. 2020. Human Perfection in Byzantine Theology: Attaining the Fullness of Christ. Oxford: Oxford University Press.

Underhill, Evelyn. 1911. Mysticism: A Study in the Nature and Development of Spiritual Consciousness. New York: E. P. Dutton.

Ware, Kallistos. 1986. Symeon the New Theologian. In The Study of Spirituality. Edited by Cheslyn Jones, Geoffrey Wainwright and SJ Edward Yarnold. New York: Oxford University Press, pp. 235-42.

Zizioulas, John D. 2006. Communion and Otherness. Edited by Paul McPartlan. London and New York: T \& T Clark. 